\title{
Low-input Performance of Zoysiagrass (Zoysia spp.) Cultivars Maintained under Dense Tree Shade
}

\author{
B.G. Wherley ${ }^{1}$, P. Skulkaew, A. Chandra, A.D. Genovesi, \\ and M.C. Engelke \\ Texas AgriLIFE Research and Extension Center, 17360 Coit Road, Dallas, \\ $T X 75252-6599$
}

Additional index words. Zoysia japonica, Zoysia matrella, shade tolerance

Abstract. A 3-year study was conducted to evaluate the comparative performance of
zoysiagrass (Zoysia spp.) cultivars for shaded environments in which inputs are
minimized. Included in the study were commercial cultivars Diamond, Cavalier, Royal,
Shadow Turf, Zorro, Zeon, Jamur, Crowne, Palisades, and Meyer. In July 2006 , grass
plugs were planted in a shade nursery comprised of live oak trees providing $89 \%$ shade.
From 2007 to 2009 , turf plots were periodically evaluated for quality, density, color,
vertical canopy height, and extent of lateral spread. Overall turfgrass quality was
noticeably reduced by the heavily shaded environment; however, some cultivars attained
acceptable levels during midsummer periods. A turf performance index (TPI) was
generated for ranking the cultivars that represented the number of times an entry
occurred in the top statistical group across all parameters and rating dates. 'Royal',
'Zorro', and 'Shadow Turf' were the cultivars ranking in the top statistical grouping
most often throughout the study. The results suggest that $Z$. matrellas may be better
adapted than $Z$. japonicas for heavily shaded environments where inputs are conserved.

It is estimated that $20 \%$ to $25 \%$ of turfgrasses are maintained in some degree of shade from buildings, trees, or shrubs (Beard, 1973). Tree shade represents, arguably, the most stressful of these environments for the establishment and persistence of turfgrass, because it simultaneously reduces light intensity and alters the red:far-red ratio of sunlight (Bell and Danneberger, 1999; Wherley et al., 2005). Changes in microclimate (Giesler et al., 2000) and root competition (Whitcomb, 1972; Whitcomb and Roberts, 1973) associated with tree shade further exacerbate the situation. Shade-avoidance responses by turfgrasses often culminate in undesirable morphological changes, including increased leaf elongation, internode length, and plant height as well as decreased tillering and root:shoot ratio (Shnyder and Nelson, 1989; Tan and Qian, 2003; Wherley et al., 2005; Winstead and Ward, 1974). Compared with plants grown in full sun, shaded plants exhibit lower rates of photosynthesis (Alexander and McCloud, 1962), which leads to a reduction in total nonstructural carbohydrates (Burton et al., 1959; Shnyder and Nelson, 1989). As a result, stand density often declines over time as individual tillers die and cannot be replaced as a result of a lack of available photosynthate. Turfgrass persistence in shade is therefore commonly limited as a result of development of a weakened, thinned turfgrass stand with an increased vulnerability to damage from a host of factors, including

Received for publication 10 Mar. 2011. Accepted for publication 5 May 2011

${ }^{1}$ To whom reprint requests should be addressed; e-mail b-wherley@tamu.edu. traffic (Cockerham et al., 1994; Jiang et al., 2003), winter injury (Steinke and Stier, 2004), and disease pressure (Giesler et al., 2000; Vargas and Beard, 1981; Zarlengo et al., 1994).

Zoysiagrass is a warm-season turfgrass that is increasing in popularity throughout the transition zone and southern United States. It has gained recognition as a low-maintenance turfgrass, primarily because of its minimal nutritional and mowing requirements relative to other turfgrass species (Christians and Engelke, 1994). Traditionally used for lawns, the species possesses broad genetic and morphological diversity (Anderson, 2000), which has in recent years led to development of varieties that are used on golf course tees, fairways, and greens (Engelke et al., 2002a, 2002b). Relative to other warm-season species, zoysiagrass possesses good shade tolerance (Beard, 1973; Stier and Gardner, 2008) and therefore has developed a niche for use in shady areas of lawns and golf courses where less shade-tolerant varieties of turfgrass are unable to persist.

Minimal research has been published regarding the comparative performance of zoysiagrass cultivars in natural shade. Riffel et al. (1995) evaluated zoysiagrass shade tolerance under $90 \%$ tree shade and identified 'Diamond' and 'Zorro' as two of the top performers in their evaluations. More recently, Sladek et al. (2009) evaluated the growth response of six potted zoysiagrass ecotypes under two levels of artificial shade under greenhouse culture. The authors reported that under 50\% shade, all ecotypes exhibited positive changes in plug diameter, although quality was not always deemed acceptable. Levels of $90 \%$ shade proved more challenging, because acceptable turfgrass quality was difficult to achieve and plug diameters actually declined for the many of the ecotypes. The authors found that 'Diamond' and 'Shadow Turf' were two of the more shade-tolerant zoysiagrasses in their study. It is not known to what extent these findings would be relevant to the natural shade environment, although the authors did note that further shade evaluation of zoysiagrasses under more practical field research conditions was needed.

The need to reduce environmental impacts from managed landscapes emphasizes the importance of identifying turfgrass species and varieties that can be managed with reduced inputs. Although data were recently published for cool-season turfgrass systems (Watkins et al., 2011), information on low-input warmseason turfgrass options are lacking. Commonly, as landscapes age, grasses must be capable of adapting to and persisting as a functional turfgrass system when subjected to increasing levels of tree shade. Gardner and Taylor (2002) examined the change in coolseason turfgrass species and cultivars over time when maintained as a low-input, shaded environment in the Midwest. Data of this type for warm-season systems are unavailable.

Although St. Augustinegrass is the most shade-tolerant warm-season turfgrass (Beard, 1973; Stier and Gardner, 2008), it can often require a higher level of cultural intensity than zoysiagrass in terms of nitrogen fertilization, irrigation, and mowing frequency (Christians and Engelke, 1994; Turgeon, 2002). Therefore, identification of zoysiagrass cultivars adapted for low-input, shaded environments where inputs are conserved is of increasing importance. The objective of this study was to compare over a 3-year period the shade performance of 10 commercially available zoysiagrass cultivars maintained as a low-maintenance groundcover in heavy tree shade.

\section{Materials and Methods}

This study was conducted from June 2006 through Nov. 2009 at the Texas AgriLIFE Research \& Extension Center in Dallas, TX. The field study was carried out under a shade nursery comprised of $\approx 40$-year-old live oak (Quercus virginiana) trees that had been planted as a three-row $\times$ eight-row stand on 6-m centers. Tree limbs had been pruned up to a height of $3 \mathrm{~m}$ above the ground before the initiation of the study. The tree canopy caused an $89 \pm 0.5 \%$ reduction in photosynthetic photon flux $(P P F)$ at ground level, based on 12 measurements obtained randomly throughout the nursery at solar noon on a clear August day using a handheld LI-COR 250 light meter (LI-COR Biosciences, Lincoln, NE). $P P F$ readings obtained during January demonstrated similar overall light reductions relative to full sun measurements. Soil texture at the study site was Houston black clay (fine, montmorillonitic, thermic, Udic, Pellustert). Soil was measured to have $\mathrm{pH}$ of 7.8 and contained $2.1 \%$ organic carbon. The study was arranged in the center of the live oak tree nursery such that $\mathrm{a} \approx 3.7-\mathrm{m}$ border existed between the study perimeter and the outer drip line of the trees on all sides. 
In July $2006,25.8-\mathrm{cm}^{2}$ grass plugs $(5.08 \mathrm{~cm} \times$ $5.08 \mathrm{~cm}$ ) were planted into the center of each $0.36-\mathrm{m}^{2}$ plot. The study was arranged in a completely randomized block design with three replicates per cultivar. Commercially available zoysiagrass cultivars included 'Shadow Turf', 'Diamond', 'Cavalier', 'Royal', 'Zorro', 'Crowne', 'Palisades', 'Meyer', 'Zeon', and 'Jamur' (Table 1). A collection of experimental zoysiagrass lines developed at Texas AgriLife Research were also evaluated in the trial but have not been included in this report. plots were fertilized with a complete starter fertilizer [7-7-7 (N- $\left.\mathrm{P}_{2} \mathrm{O}_{5}-\mathrm{K}_{2} \mathrm{O}\right)$; Grigg Bros., Albion, ID] at a rate of $37 \mathrm{~kg} \mathrm{~N} / \mathrm{ha}$ and irrigated regularly to prevent drying out of soil and plant wilt. For the remainder of the study, plots received a single annual application of sulfur-coated urea supplied in May of each year at a rate of $37 \mathrm{~g} \mathrm{~N} / \mathrm{m}^{2}$. During the establishment year, plots were irrigated one to two times weekly. After the establishment year, irrigation was only provided if wilt became evident in plots. This resulted in irrigation being applied every 2 to 3 weeks throughout the summer months, primarily to supplement natural rainfall during extremely dry periods. Given the historical precipitation for the site of $84 \mathrm{~cm} /$ year, average to below-average precipitation was received during the 2006 (establishment) and 2008 seasons ( $74 \mathrm{~cm}$ and $78 \mathrm{~cm}$, respectively), whereas above-average precipitation was received for the 2007 and 2009 seasons (140 cm and $108 \mathrm{~cm}$, respectively). Plots were mowed three times annually between May and October at a height of $9 \mathrm{~cm}$. Tree leaves that fell onto plots during the course of the study were blown off when necessary. No herbicide, insecticides, or fungicides were applied over the duration of the study.

Turfgrass quality, color, density, lateral spread, and vertical canopy height ratings were recorded from 2007 to 2009 . Turfgrass to 9 scale in which $1=$ undesirable, $9=$ highest possible, and $5=$ minimally acceptable. Color was also visually rated on a 1 to 9 scale in which $1=$ brown, $9=$ dark green, and $5=$ minimally acceptable color. Using the same rating scale, winter color, spring green-up, and genetic color were also evaluated according to National Turfgrass Evaluation Program guidelines (Morris and Shearman, 1998). Spring green-up was evaluated in mid-March, genetic color was recorded in June, and winter color
During the initial season of establishment, quality and density were rated visually on a 1

was noted during January and/or February. Lateral spread ratings were determined by measuring the average increase in plant area relative to the original $25.8-\mathrm{cm}^{2}$ plug. Vertical canopy height measurements were recorded in Sept. 2007 and in Aug. 2008 after 8 weeks without mowing and are the average of two measurements randomly taken within each plot by lifting up an $81-\mathrm{cm}^{2}$ area of the turf canopy and using a ruler to measure the longest shoot. Top-performing entries within this parameter were identified for their more diminutive growth habit in shade. At the conclusion of the study, a cumulative TPI score was generated for each variety, representing the number of times it occurred in the top statistical grouping as determined by least significant difference across all parameters and all sampling dates.

Data for each parameter were analyzed as a completely randomized block design with repeated measures. Analysis of variance indicated a significant year $\times$ cultivar interaction. Therefore, data for the 3 years are presented separately. Fisher's least significant difference test was used to separate treatment means at the $P \leq 0.05$ level.

\section{Results}

Turf quality. Turfgrass quality ratings were taken during August, September, and December of 2007; March and November of 2008; and for all months of the 2009 season. Quality followed a seasonal pattern with the greatest levels reached during late summer for all 3 years. Not surprisingly, because of the continuously heavily shaded environment, most cultivars possessed unacceptable quality throughout the entire 3-year study (Tables 2 through 4). Despite this, 'Shadow Turf', 'Royal', and 'Diamond' each attained acceptable levels of quality (greater than 5) during the late summer rating periods in 2007 (Table 2 ). None of the cultivars showed acceptable quality levels during the 2008 growing season (Table 3). 'Royal' was the only cultivar to attain acceptable quality during any point of the 2009 season (Table 4).

Density. Density ratings were taken during summer and fall of 2007, whereas spring, summer, and fall ratings were taken for the final two seasons. Consistently throughout the study, density was noticeably highest within the $Z$. matrella cultivars. During 2007, 'Diamond' and 'Royal' showed the highest overall density

Table 1. Zoysiagrass species and cultivars evaluated in the 3-year shade study.

\begin{tabular}{lll}
\hline Scientific name & Cultivar & \multicolumn{1}{c}{ Origin } \\
\hline Z. matrella $($ L.) Merr. & Shadow Turf & Texas Tech University \\
Zeon & BladeRunner Farms, Inc. \\
Zorro & Texas AgriLIFE Research \\
Cavalier & Texas AgriLIFE Research \\
Royal & Texas AgriLIFE Research \\
Diamond & Texas AgriLIFE Research \\
& Jamur & Bladerunner Farms, Inc. \\
Z. japonica Steud. & Meyer & U.S. Dept. of Agr. \\
& Palisades & Texas AgriLIFE Research \\
& Crowne & Texas AgriLIFE Research \\
\hline
\end{tabular}

levels, whereas 'Meyer' and 'Palisades' exhibited the lowest (Table 2). In 2008, 'Diamond', 'Royal', 'Zorro', and 'Cavalier' consistently had the highest overall density, whereas 'Meyer' showed the lowest density (Table 3). By 2009, density declined noticeably in many cultivars, although 'Shadow Turf' and 'Royal' continued to exhibit acceptable levels (Table 4).

Lateral spread. Grasses commonly respond to shade by allocating resources to increase upright growth and reduce tillering (Shnyder and Nelson, 1989; Tan and Qian, 2003; Wherley et al., 2005; Winstead and Ward, 1974). Therefore, the ability to spread laterally is an important attribute for shaded turfgrass both in terms of establishment as well as recovery from wear or damage. Lateral spread varied considerably among cultivars in this study with observed growth increases ranging from one to five times the original plug diameters by the end of the 2007 season. Cultivars with the most aggressive lateral growth were the Z. matrella cultivars Shadow Turf, Royal, and Zorro, which ranked in the top statistical group in the end of season December ratings (Table 2). 'Royal', 'Jamur', 'Zorro', 'Crowne', 'Palisades', and 'Shadow Turf' all ranked in the top statistical group at the end of 2008 (Table 3). The final lateral spread data were collected in May 2009, at which time 'Royal', 'Palisades', 'Zorro', and 'Crowne' all ranked within the top statistical grouping and had the greatest lateral spread (Table 4).

Vertical canopy height. A common shadeavoidance response observed for many shadeintolerant species is rapid leaf elongation, resulting in a taller, more upright plant canopy. Identification of cultivars that maintain a more decumbent growth habit in shade may suggest more favorable allocation of carbohydrates into the crown and below-ground plant parts. More practically, such grasses could be better suited for low-maintenance situations where mowing is minimized. Based on vertical height measurements taken during 2007, 'Diamond' and 'Shadow Turf' possessed the shortest vertical height $(7.0$ and $7.8 \mathrm{~cm}$, respectively), whereas 'Jamur', 'Palisades', and 'Crowne' (21.7, 21.5, and $19.3 \mathrm{~cm}$, respectively) produced the tallest and most elongate growth (Table 2). A similar trend was observed in 2008 with 'Diamond' and 'Shadow Turf' ( 8.3 and $9.7 \mathrm{~cm}$, respectively) again maintaining the shortest canopy heights. Vertical heights for the $Z$. japonica cultivars Palisades, Crowne, Meyer, and Jamur were more than double those of the Z. matrella types 'Diamond' and 'Shadow Turf' (Table 3).

Spring color. Zoysiagrass cultivars were also evaluated for rate of spring green-up during mid- to late March of each growing season. When taken collectively, the Z. japonica cultivars showed a tendency toward faster green-up over the 3 years. In 2007, all cultivars exhibited fairly rapid rates of spring green-up with the exception of 'Diamond', which lagged slightly behind (Table 2). 'Shadow Turf', 'Zorro', 'Palisades', and 'Diamond' showed acceptable color in the 2008 spring green-up ratings, although as a group, green-up was 


\begin{tabular}{|c|c|c|c|c|c|c|c|c|c|c|c|c|c|c|c|c|c|}
\hline \multirow[b]{2}{*}{ Entry } & \multicolumn{11}{|c|}{ Spreading $^{\mathrm{t}}$} & \multicolumn{6}{|c|}{ Turf quality $^{\mathrm{u}}$} \\
\hline & March & April & May & June & July & August & September & October & \multicolumn{2}{|c|}{ December } & Avg & \multicolumn{4}{|c|}{ September } & December & Avg \\
\hline Royal & 1.3 & $1.7 \mathrm{a}$ & $2.0 \mathrm{a}$ & 2.3 & $4.0 \mathrm{a}$ & $3.3 \mathrm{a}$ & $3.7 \mathrm{a}$ & $4.0 \mathrm{a}$ & \multirow{2}{*}{\multicolumn{2}{|c|}{$\begin{array}{l}4.0 \mathrm{a} \\
5.0 \mathrm{a}\end{array}$}} & 2.9 & \multicolumn{3}{|c|}{$5.0 \mathrm{a}$} & & $3.7 \mathrm{a}$ & $4.4 \mathrm{a}$ \\
\hline Shadow Turf & $2.0 \mathrm{a}$ & $2.0 \mathrm{a}$ & $2.0 \mathrm{a}$ & $3.5 \mathrm{a}$ & $3.5 \mathrm{a}$ & $3.5 \mathrm{a}$ & $4.0 \mathrm{a}$ & $3.5 \mathrm{a}$ & & & 3.2 & \multicolumn{4}{|c|}{$\begin{array}{l}4.5 \mathrm{a} \\
4.0 \mathrm{a}\end{array}$} & $3.5 \mathrm{a}$ & $4.4 \mathrm{a}$ \\
\hline Palisades & $1.7 \mathrm{a}$ & $2.0 \mathrm{a}$ & $2.0 \mathrm{a}$ & 2.3 & 2.3 & $2.3 \mathrm{a}$ & $2.7 \mathrm{a}$ & $3.0 \mathrm{a}$ & & & 2.3 & & 4.0 & & $0 \mathrm{a}$ & $3.3 \mathrm{a}$ & $3.8 \mathrm{a}$ \\
\hline Jamur & 1.0 & $1.7 \mathrm{a}$ & $1.7 \mathrm{a}$ & 2.0 & 2.0 & $2.3 \mathrm{a}$ & 2.3 & $2.7 \mathrm{a}$ & & & 2.0 & & $4.7 \mathrm{a}$ & & & 2.7 & 3.7 \\
\hline Crowne & 1.0 & $1.7 \mathrm{a}$ & $1.7 \mathrm{a}$ & 1.7 & 2.3 & 2.0 & 2.3 & $3.3 \mathrm{a}$ & & & 2.1 & & $4.7 \mathrm{a}$ & & & 2.7 & 3.7 \\
\hline Meyer & 1.0 & $1.3 \mathrm{a}$ & 1.3 & 1.3 & 1.3 & 1.3 & 1.3 & 1.0 & & & 1.2 & & 3.0 & & & 2.0 & 2.7 \\
\hline $\operatorname{LSD}_{0.05^{\mathrm{y}}}$ & 0.6 & 0.8 & 0.6 & 0.9 & 1.6 & 1.3 & 1.5 & 2.0 & & & 0.8 & & 1.1 & & & 0.9 & 0.7 \\
\hline & Genetic & & ring & & Density $^{\mathrm{v}}$ & & al & & Seaso & al colc & & & & & nter color ${ }^{\mathrm{N}}$ & & 2007 \\
\hline Entry & color $^{\mathrm{w}}$ & gree & n-up ${ }^{w}$ & Summer & Fall & Avg & ht $(\mathrm{cm})$ & April & July & Octo & & Avg & $\overline{\operatorname{Jan}}$ & lary & February & Avg & $\mathrm{TPI}^{\mathrm{x}}$ \\
\hline$\overline{\text { Zorro }}$ & 6.3 & & $3 a$ & 4.7 & $5.0 \mathrm{a}$ & 4.8 & $11.7 \mathrm{a}$ & $7.0 \mathrm{a}$ & $8.0 \mathrm{a}$ & 6.7 & & $7.2 \mathrm{a}$ & 4. & & $4.3 \mathrm{a}$ & $4.2 \mathrm{a}$ & 19 \\
\hline Royal & $7.0 \mathrm{a}$ & & $7 \mathrm{a}$ & $5.3 \mathrm{a}$ & $5.3 \mathrm{a}$ & $5.3 \mathrm{a}$ & $11.3 \mathrm{a}$ & $7.0 \mathrm{a}$ & $8.0 \mathrm{a}$ & 6.7 & & $7.2 \mathrm{a}$ & 3. & & 4.0 & 3.5 & 18 \\
\hline Crowne & $7.0 \mathrm{a}$ & & $7 \mathrm{a}$ & $5.3 \mathrm{a}$ & 4.3 & 4.8 & 18.0 & $7.0 \mathrm{a}$ & $7.7 \mathrm{a}$ & 6.0 & & $6.9 \mathrm{a}$ & 3. & & 4.0 & 3.8 & 10 \\
\hline Zeon & 6.3 & & $0 \mathrm{a}$ & $5.3 \mathrm{a}$ & $4.7 \mathrm{a}$ & $5.0 \mathrm{a}$ & 15.0 & $6.3 \mathrm{a}$ & $8.0 \mathrm{a}$ & 7.0 & & $7.1 \mathrm{a}$ & 3. & & 4.0 & 3.8 & 11 \\
\hline Cavalier & 6.3 & & $3 \mathrm{a}$ & 5.0 & $5.0 \mathrm{a}$ & $5.0 \mathrm{a}$ & 13.0 & $6.7 \mathrm{a}$ & $8.0 \mathrm{a}$ & 6.7 & & $7.1 \mathrm{a}$ & 3. & & $4.3 \mathrm{a}$ & 3.7 & 7 \\
\hline Meyer & $7.0 \mathrm{a}$ & & $0 \mathrm{a}$ & 4.7 & 3.0 & 3.8 & 14.0 & $7.0 \mathrm{a}$ & $8.0 \mathrm{a}$ & 5.3 & & 6.8 & 2. & & 4.0 & 3.0 & 5 \\
\hline $\operatorname{LSD}_{0.05^{y}}$ & 0.9 & 1 & & 1.9 & 1.5 & 1.5 & 4.5 & 1.3 & 0.4 & 1.2 & & 0.4 & 1. & & 0.5 & 0.6 & \\
\hline
\end{tabular}

${ }^{2}$ Values followed by 'a' ranked in the top statistical group based on Fisher's LSD for the given parameter and date.

'Means were separated using Fisher's least significance difference (LSD) test $(P \leq 0.05)$. Means with an "a" rating were in the top statistical group.

${ }^{\mathrm{x}} \mathrm{TPI}$ is the turf performance index representing the number of times an entry occurred in the top statistical group.

${ }^{\text {w }}$ Color ratings: $9=$ darkest green; $5=$ minimally acceptable color; $1=$ straw brown turf.

"Density: 9 = maximum density; 5 = minimally acceptable density, $1=$ lowest density.

"Quality: 9 = maximum quality; 5 = minimally acceptable quality; 1 = lowest quality.

tSpreading: fold increase in measured plant area relative to the original $25.8-\mathrm{cm}^{2} \mathrm{plug}$.

Table 3. Year 2008 ratings for the zoysiagrass shade study at Texas AgriLIFE Research, Dallas, TX. ${ }^{z}$

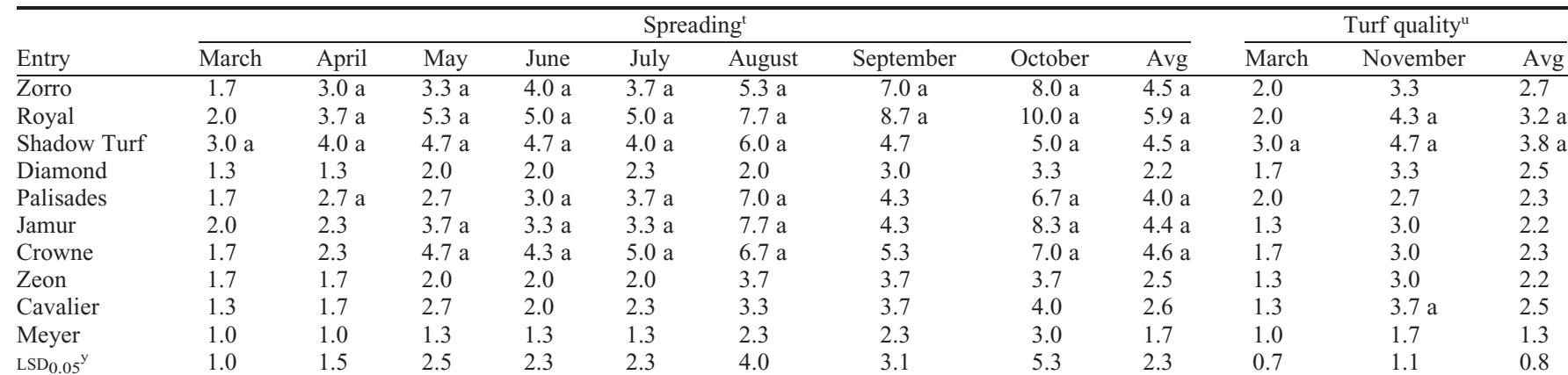

\begin{tabular}{|c|c|c|c|c|c|c|c|c|c|c|c|c|c|}
\hline \multirow[b]{2}{*}{ Entry } & \multirow{2}{*}{$\begin{array}{l}\text { Genetic } \\
\text { color }^{\mathrm{w}}\end{array}$} & \multirow{2}{*}{$\begin{array}{c}\text { Spring } \\
\text { green-up }^{\mathrm{w}}\end{array}$} & \multicolumn{4}{|c|}{ Density $^{v}$} & \multirow{2}{*}{$\begin{array}{l}\text { Vertical } \\
\text { ht }(\mathrm{cm})\end{array}$} & \multicolumn{4}{|c|}{ Fall color ${ }^{\mathrm{w}}$} & \multirow{2}{*}{$\begin{array}{l}\text { Winter } \\
\text { color }^{\mathrm{w}}\end{array}$} & \multirow[b]{2}{*}{2008 TPI $^{\mathrm{x}}$} \\
\hline & & & Spring & Summer & Fall & Avg & & September & October & November & Avg & & \\
\hline Royal & $6.7 \mathrm{a}$ & $4.3 \mathrm{a}$ & $7.3 \mathrm{a}$ & $5.7 \mathrm{a}$ & $5.3 \mathrm{a}$ & $6.1 \mathrm{a}$ & 14.7 & $6.3 \mathrm{a}$ & $5.7 \mathrm{a}$ & 4.3 & 5.4 & 3.3 & 15 \\
\hline Shadow Turf & $6.0 \mathrm{a}$ & $5.5 \mathrm{a}$ & 4.5 & 4.0 & $4.5 \mathrm{a}$ & 4.3 & $9.5 \mathrm{a}$ & $5.5 \mathrm{a}$ & 5.5 & $6.0 \mathrm{a}$ & $5.7 \mathrm{a}$ & $5.5 \mathrm{a}$ & 16 \\
\hline Palisades & $5.7 \mathrm{a}$ & $5.0 \mathrm{a}$ & 5.0 & 5.0 & $4.0 \mathrm{a}$ & 4.7 & 22.3 & $6.3 \mathrm{a}$ & $7.0 \mathrm{a}$ & $6.0 \mathrm{a}$ & $6.4 \mathrm{a}$ & 4.0 & 11 \\
\hline Jamur & $6.0 \mathrm{a}$ & $4.3 \mathrm{a}$ & 4.3 & 4.0 & 3.7 & 4.0 & 19.7 & $6.3 \mathrm{a}$ & $6.7 \mathrm{a}$ & $6.0 \mathrm{a}$ & $6.3 \mathrm{a}$ & 3.7 & 10 \\
\hline Crowne & $5.7 \mathrm{a}$ & $4.7 \mathrm{a}$ & 5.0 & 4.0 & 3.3 & 4.1 & 21.0 & $6.0 \mathrm{a}$ & $6.3 \mathrm{a}$ & $6.7 \mathrm{a}$ & $6.3 \mathrm{a}$ & 3.3 & 11 \\
\hline Meyer & 2.7 & 2.0 & 4.3 & 3.7 & 2.3 & 3.4 & 21.3 & $6.0 \mathrm{a}$ & $7.3 \mathrm{a}$ & 5.7 & $6.3 \mathrm{a}$ & 1.7 & 2 \\
\hline $\operatorname{LSD}_{0.05}{ }^{\mathrm{y}}$ & 2.2 & 1.9 & 2.0 & 1.6 & 1.7 & 1.4 & 5.0 & 1.2 & 1.8 & 0.8 & 0.9 & 1.2 & \\
\hline
\end{tabular}

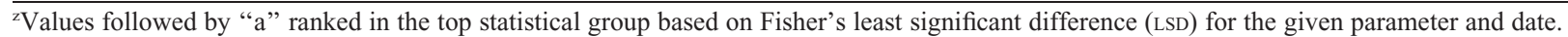

${ }^{y}$ Means were separated using Fisher's LSD test $(P \leq 0.05)$. Means with an "a" rating were in the top statistical group.

${ }^{x}$ TPI is the turf performance index representing the number of times an entry occurred in the top statistical group.

${ }^{\text {w }}$ Color ratings: $9=$ darkest green; $5=$ minimally acceptable color; $1=$ straw brown turf.

'Density: $9=$ maximum density; $5=$ minimally acceptable density, $1=$ lowest density.

"Quality: 9 = maximum quality; $5=$ minimally acceptable quality; $1=$ lowest quality.

'Spreading: fold increase in measured plant area relative to the original $25.8-\mathrm{cm}^{2}$ plug.

delayed relative to the previous season (Table 3). 'Palisades', 'Meyer', 'Jamur', 'Crowne', and 'Shadow Turf' exhibited the most rapid green-up during the 2009 evaluation with five of the six Z. matrella cultivars exhibiting slower rates of green-up (Table 4). Field observations indicate that Z. matrella genotypes tend to retain better green color during winter than $Z$. japonica cultivars under closely 


\begin{tabular}{|c|c|c|c|c|c|c|c|c|c|c|c|c|c|c|}
\hline \multirow[b]{2}{*}{ Entry } & \multicolumn{14}{|c|}{ Turf quality $^{\mathrm{t}}$} \\
\hline & January & February & March & April & May & June & July & August & September & \multicolumn{2}{|l|}{ October } & November & December & $\overline{A v g}$ \\
\hline Zorro & 2.3 & $2.7 \mathrm{a}$ & $3.3 \mathrm{a}$ & $3.7 \mathrm{a}$ & $4.0 \mathrm{a}$ & $4.7 \mathrm{a}$ & $3.7 \mathrm{a}$ & $3.3 \mathrm{a}$ & $4.0 \mathrm{a}$ & \multicolumn{2}{|l|}{$4.0 \mathrm{a}$} & $3.3 \mathrm{a}$ & $2.3 \mathrm{a}$ & $3.4 \mathrm{a}$ \\
\hline Royal & $3.0 \mathrm{a}$ & $3.0 \mathrm{a}$ & $4.0 \mathrm{a}$ & $4.3 \mathrm{a}$ & $4.3 \mathrm{a}$ & $5.0 \mathrm{a}$ & $4.7 \mathrm{a}$ & $4.0 \mathrm{a}$ & $4.3 \mathrm{a}$ & \multicolumn{2}{|l|}{$4.0 \mathrm{a}$} & $3.7 \mathrm{a}$ & $2.7 \mathrm{a}$ & $3.9 \mathrm{a}$ \\
\hline Shadow Turf & $3.5 \mathrm{a}$ & $3.5 \mathrm{a}$ & $4.0 \mathrm{a}$ & $3.5 \mathrm{a}$ & 3.0 & 3.0 & 2.7 & $3.3 \mathrm{a}$ & $4.3 \mathrm{a}$ & \multicolumn{2}{|l|}{2.0} & 2.3 & 2.0 & $3.9 \mathrm{a}$ \\
\hline Diamond & $3.0 \mathrm{a}$ & 2.3 & $3.7 \mathrm{a}$ & 3.0 & $3.3 \mathrm{a}$ & $4.3 \mathrm{a}$ & $4.0 \mathrm{a}$ & $4.0 \mathrm{a}$ & $3.7 \mathrm{a}$ & \multicolumn{2}{|l|}{$4.0 \mathrm{a}$} & $3.3 \mathrm{a}$ & $3.0 \mathrm{a}$ & $3.5 \mathrm{a}$ \\
\hline Palisades & 2.0 & 2.0 & $3.0 \mathrm{a}$ & 2.3 & $3.3 \mathrm{a}$ & $4.0 \mathrm{a}$ & 3.0 & $4.0 \mathrm{a}$ & 3.0 & \multicolumn{2}{|l|}{2.3} & 2.3 & $2.3 \mathrm{a}$ & 2.8 \\
\hline Jamur & 2.0 & 1.7 & $3.0 \mathrm{a}$ & 2.7 & 3.0 & 3.0 & 2.7 & $3.3 \mathrm{a}$ & 2.7 & \multicolumn{2}{|l|}{2.0} & 2.3 & 2.0 & 2.5 \\
\hline Crowne & 2.0 & 2.0 & $2.7 \mathrm{a}$ & 2.0 & $3.3 \mathrm{a}$ & 3.0 & 2.7 & $3.3 \mathrm{a}$ & 2.7 & \multicolumn{2}{|l|}{2.0} & 2.3 & 2.0 & 2.5 \\
\hline Zeon & 1.7 & 2.0 & 2.0 & 2.3 & 3.0 & 3.0 & 3.3 & 2.3 & 2.3 & \multicolumn{2}{|l|}{2.3} & 2.3 & $2.3 \mathrm{a}$ & 2.4 \\
\hline Cavalier & 2.3 & 2.3 & $3.0 \mathrm{a}$ & $3.3 \mathrm{a}$ & $3.7 \mathrm{a}$ & $4.7 \mathrm{a}$ & $4.7 \mathrm{a}$ & $3.7 \mathrm{a}$ & $4.0 \mathrm{a}$ & \multicolumn{2}{|l|}{$4.0 \mathrm{a}$} & $3.7 \mathrm{a}$ & $3.0 \mathrm{a}$ & $3.5 \mathrm{a}$ \\
\hline Meyer & 1.3 & 1.3 & 1.7 & 2.3 & 2.7 & 2.7 & 2.7 & 2.7 & 2.0 & \multicolumn{2}{|l|}{2.0} & 2.0 & 1.3 & 2.1 \\
\hline $\operatorname{LSD}_{0.05^{\mathrm{y}}}$ & 1.0 & 1.0 & 1.6 & 1.3 & 1.3 & 1.4 & 1.1 & 1.2 & 0.8 & \multicolumn{2}{|l|}{0.9} & 1.0 & 0.8 & 0.8 \\
\hline & \multicolumn{4}{|c|}{ Spreading $^{\mathrm{u}}$} & Genetic & \multirow{2}{*}{\multicolumn{2}{|c|}{$\begin{array}{l}\text { Spring } \\
\text { green-up }\end{array}$}} & & Density & & & & & \\
\hline Entry & March & April & May & Avg & color $^{v}$ & & & Spring & Summer & Fall & $\overline{A v g}$ & \multicolumn{2}{|c|}{ Winter color ${ }^{\mathrm{V}}$} & $2009 \mathrm{TPI}^{\mathrm{x}}$ \\
\hline Zorro & $6.0 \mathrm{a}$ & $10.7 \mathrm{a}$ & $12.3 \mathrm{a}$ & $9.7 \mathrm{a}$ & $6.3 \mathrm{a}$ & & 4.7 & $4.7 \mathrm{a}$ & $4.7 \mathrm{a}$ & $4.0 \mathrm{a}$ & $4.4 \mathrm{a}$ & 3. & & 18 \\
\hline Royal & $8.3 \mathrm{a}$ & $12.3 \mathrm{a}$ & $16.7 \mathrm{a}$ & $12.4 \mathrm{a}$ & 6.0 & & 4.3 & $5.7 \mathrm{a}$ & $5.3 \mathrm{a}$ & $4.7 \mathrm{a}$ & $5.2 \mathrm{a}$ & 3. & & 18 \\
\hline Shadow Turf & $5.0 \mathrm{a}$ & $6.0 \mathrm{a}$ & 7.0 & 6.0 & $6.7 \mathrm{a}$ & & $5.5 \mathrm{a}$ & $5.5 \mathrm{a}$ & $5.3 \mathrm{a}$ & $5.3 \mathrm{a}$ & $5.4 \mathrm{a}$ & 5. & & 14 \\
\hline Diamond & 3.3 & $5.0 \mathrm{a}$ & 5.7 & 4.7 & $7.0 \mathrm{a}$ & & 4.3 & $5.0 \mathrm{a}$ & $5.7 \mathrm{a}$ & $4.0 \mathrm{a}$ & $4.9 \mathrm{a}$ & 4. & & 16 \\
\hline Palisades & $6.7 \mathrm{a}$ & $8.7 \mathrm{a}$ & $12.7 \mathrm{a}$ & $9.3 \mathrm{a}$ & $7.7 \mathrm{a}$ & & $7.0 \mathrm{a}$ & 2.0 & 2.7 & 2.3 & 2.3 & $4 .($ & & 11 \\
\hline Jamur & $6.7 \mathrm{a}$ & $10.3 \mathrm{a}$ & 9.0 & $8.7 \mathrm{a}$ & $7.7 \mathrm{a}$ & & $6.0 \mathrm{a}$ & 2.7 & 2.7 & 1.7 & 2.3 & $4 .($ & & 7 \\
\hline Crowne & $6.0 \mathrm{a}$ & $8.7 \mathrm{a}$ & $10.3 \mathrm{a}$ & $8.3 \mathrm{a}$ & $7.3 \mathrm{a}$ & & $6.0 \mathrm{a}$ & 2.3 & 2.3 & 2.3 & 2.3 & $4 .($ & & 9 \\
\hline Zeon & 2.7 & 4.7 & 5.3 & 4.2 & $7.0 \mathrm{a}$ & & 3.3 & 3.3 & 3.0 & 2.3 & 2.9 & 3.3 & & 2 \\
\hline Cavalier & 4.0 & 4.7 & 7.7 & 5.4 & $6.3 \mathrm{a}$ & & 4.7 & $4.0 \mathrm{a}$ & $4.7 \mathrm{a}$ & $4.7 \mathrm{a}$ & $4.4 \mathrm{a}$ & 4. & & 15 \\
\hline Meyer & 2.7 & $6.7 \mathrm{a}$ & 6.7 & 5.3 & $7.7 \mathrm{a}$ & & $6.7 \mathrm{a}$ & 2.0 & 2.0 & 1.7 & 1.9 & 3.3 & & 3 \\
\hline$\underline{L S D}_{0.05^{y}}$ & 3.6 & 7.4 & 7.4 & 6.1 & 1.4 & & 1.6 & 1.8 & 1.4 & 1.5 & 1.3 & 1. & & \\
\hline
\end{tabular}

${ }^{z}$ Values followed by "a" ranked in the top statistical group based on Fisher's least significant difference (LSD) for the given parameter and date.

"Means were separated using Fisher's LSD test $(P \leq 0.05)$. Means with an "a" rating were in the top statistical group.

${ }^{\mathrm{x}} \mathrm{TPI}$ is the turf performance index representing the number of times an entry occurred in the top statistical group.

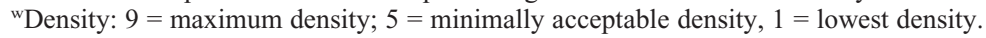

${ }^{v}$ Color ratings: $9=$ darkest green; $5=$ minimally acceptable color; $1=$ straw brown turf.

uSpreading: fold increase in measured plant area relative to the original $25.8-\mathrm{cm}^{2}$ plug.

${ }^{\mathrm{t}}$ Quality: 9 = maximum quality; 5 = minimally acceptable quality; $1=$ lowest quality.

mowed conditions; however, they also tend to be less aggressive in terms of shoot growth production. Therefore, it is likely that at the time that spring green-up ratings were taken, the new growth emerging from $Z$. matrella crowns had not yet surfaced above the dormant, brown canopy remaining from the prior season's growth under these low-maintenance conditions. This likely explains the trend toward delayed spring green-up observed in many of the Z. matrella plots.

Genetic color. Genetic color was evaluated in June each season and fluctuated from year to year with no one particular cultivar consistently outperforming the others (Table 2 through 4). In 2007, all varieties were deemed to have acceptable levels of genetic color with 'Diamond', 'Royal', 'Palisades', 'Jamur', 'Crowne', and 'Meyer' ranking in the top statistical group (Table 2). In 2008, 'Zorro' and 'Meyer' were considered to have unacceptable genetic color in the study (4.7 and 2.7, respectively), whereas all other varieties received acceptable ratings (Table 3). By 2009, all varieties once again exhibited acceptable genetic color with only 'Royal' failing to rank in the top statistical group (Table 4).

Seasonal and winter color. With the exception of 'Shadow Turf' and 'Diamond', which showed acceptable color during the winter of multiple years, zoysiagrass color was generally unacceptable during winter months (Tables 2 through 4). Acceptable color was attained as early as mid to late-March (green-up) for most cultivars and peaked in midsummer. Some cultivars continued to retain acceptable color well into November (Table 3). In 2007, all cultivars with the exception of 'Meyer', 'Crowne', and 'Shadow Turf' ranked in the top statistical group across the April, July, and October rating periods (Table 2). Fall color was also recorded from September through November in 2008. Cultivars that consistently ranked in the top statistical group across all fall months included 'Palisades', 'Jamur', 'Crowne', and 'Shadow Turf' (Table 3).

Turf performance index. A TPI was generated for each season as well as at the conclusion of the study as a means of identifying the top-performing cultivars in this trial (Table 5 ). Based on this cumulative 3 -year TPI, the $Z$. matrella cultivars Royal, Zorro, and Shadow Turf were found to be the top three performing cultivars in the study, whereas 'Palisades' was the top-performing $Z$. japonica. Our data suggest that 'Zeon' and 'Meyer' were the least adapted of the tested cultivars for low-input, heavily shaded environments.

\section{Discussion}

This study is one of the first to evaluate comparative performance of a range of zoysiagrass cultivars in a low-input, naturally shaded environment. Although there have been limited published data regarding comparative zoysiagrass shade performance, it is difficult to compare our results in light of previous research, primarily as a result of differences in cultural intensity.

One of the most interesting findings of this study was the wide genetic variability among
Table 5. Cumulative 3-year turf performance index for the zoysiagrass cultivars.

\begin{tabular}{lcccc}
\hline & \multicolumn{4}{c}{ TPI $^{z}$} \\
\cline { 2 - 5 } Entry & 2007 & 2008 & 2009 & Total \\
Royal & 18 & 15 & 18 & 51 \\
Zorro & 19 & 12 & 18 & 49 \\
Shadow Turf & 16 & 16 & 14 & 46 \\
Diamond & 14 & 9 & 16 & 39 \\
Palisades & 14 & 11 & 11 & 36 \\
Crowne & 10 & 11 & 9 & 30 \\
Cavalier & 7 & 6 & 15 & 28 \\
Jamur & 10 & 10 & 7 & 27 \\
Zeon & 11 & 4 & 2 & 17 \\
Meyer & 5 & 2 & 3 & 10 \\
\hline
\end{tabular}

${ }^{2}$ TPI is the turf performance index representing the number of times an entry occurred in the top statistical group across all parameters.

zoysiagrass cultivars for their ability to persist in heavy shade. Although all cultivars showed increases in lateral spread during the study, a wide range of spread was observed. Similarly, Sladek et al. (2009) reported that after 12 weeks in $90 \%$ shade, half of the zoysiagrass genotypes used in their study had increased in diameter ('Diamond', 'Shadow Turf', and 'DALZ 0501'), whereas 'Emerald', 'Meyer', and 'Zorro' significantly decreased in size. The observation that 'Zorro' performed relatively poorly in their greenhouse study contradicts our data as well as those of Riffel et al. (1995), who found it to be one of the top-performing cultivars under similar levels of shade. Because their work was conducted over the winter months, $90 \%$ shade would have yielded much 
lower levels of solar radiation than that of the present study and likely explains the reported decline for half of their genotypes.

Interestingly, four of the 10 cultivars used in our study that emerged as top performers, based on TPI, were Z. matrella cultivars. Conversely, four of the bottom six were Z . japonica cultivars. Aside from anecdotal evidence, few publications have reported that Z. matrella cultivars are better adapted to heavy shade than Z. japonica cultivars. Riffel et al. (1995) observed that $Z$. matrella genotypes maintained $\approx 50 \%$ to $75 \%$ groundcover but reported that Meyer maintained only $25 \%$ cover in $90 \%$ shade. There is also a growing body of literature that supports the shade tolerance of $Z$. matrella cultivars Diamond and Shadow Turf (Engelke et al., 2002a; Qian and Engelke, 1999; Qian et al., 1998; Riffel et al., 1995; Sladek et al., 2009); however, data concerning the shade tolerance of 'Royal' are lacking. Numerous reports confirm the relatively poor tolerance of $Z$. japonica 'Meyer' to heavy shade (Ervin et al., 2002; Riffel et al., 1995; Sladek et al., 2009).

The average performance of 'Diamond' relative to other $Z$. matrella cultivars in this study was somewhat surprising given previous reports of its excellent shade tolerance under more intensively managed conditions (Engelke et al., 2002a; Qian and Engelke, 1999; Qian et al., 1998). Although this could have been attributable to the reduced levels of irrigation or nitrogen fertility, it was more likely a response to the elevated height of cut in our study. 'Diamond' is an extremely compactgrowing zoysiagrass performing ideally under $1.3-\mathrm{cm}$ mowing heights. As a result of its prostrate nature, it would have been virtually unmowed throughout the study. Although mowing can be a stress, it is also an effective means of encouraging tillering and lateral spread of zoysiagrass (Hart and DeFrance, 1955). This may have contributed to the relatively minimal lateral spread observed in 'Diamond' over the study. 'Diamond' was also found to perform poorly in the 1992-1995 National Turfgrass Evaluation Program trials, possibly as a result of the higher cut at which it was maintained (Morris, 1996).

Although Z. matrella cultivars are sometimes not recommended for lawns as a result of the potentially greater level of maintenance required relative to $Z$. japonicas, these results support the idea that for low-maintenance shaded areas, they may be the better suited of the two species. Over the course of this study, cultivars Royal, Zorro, and Shadow Turf exhibited good lateral growth while generally maintaining higher density and color than the Z. japonica types 'Palisades', 'Crowne', 'Jamur', and 'Meyer'. These were some of the primary factors contributing to their superior performance in this study.

This work has evaluated performance of zoysiagrass cultivars for low-input, shaded environments. Future zoysiagrass research should be directed toward determining field performance of these and other zoysiagrass cultivars under more moderate levels of cultural intensity and shade.

\section{Literature Cited}

Alexander, C.W. and D.E. McCloud. 1962. $\mathrm{CO}_{2}$ uptake (net photosynthesis) as influenced by light intensity of isolated bermudagrass leaves contrasted to that of swards under various clipping regimes. Crop Sci. 2:132-135.

Anderson, S.J. 2000. Taxonomy of Zoysia (poaceae): Morphological and molecular variation. $\mathrm{PhD}$ diss., Texas A\&M Univ., College Station, TX.

Beard, J.B. 1973. Turfgrass: Science and culture. Prentice-Hall, Englewood Cliffs, NJ.

Bell, G. and T.K. Danneberger. 1999. Temporal shade on creeping bentgrass turf. Crop Sci. 39:1142-1146.

Burton, G.W., J.E. Jackson, and F.E. Knox. 1959. The influence of light reduction upon the production, persistence, and chemical composition of coastal bermudagrass, Cynodon dactylon. Agron. J. 51:537-542.

Christians, N.E. and M.C. Engelke. 1994. Choosing the right grass to fit the environment, p. 109. In: Leslie, A.R. (ed.). Handbook of integrated pest management. CRC Press, Boca Raton, FL.

Cockerham, S.T., V.A. Gibeault, and M. Borgonovo. 1994. Traffic effects on turfgrasses under restricted light. California Turfgrass Culture 44:1-3.

Engelke, M.C., P.F. Colbaugh, J.A. Reinert, K.B. Marcum, R.H. White, B. Ruemmele, and S.J. Anderson. 2002a. Registration of 'Diamond'. Zoysiagrass. Crop Sci. 42:304-305.

Engelke, M.C., J.A. Reinert, P.F. Colbaugh, R.H. White, B.A. Ruemmele, K.B. Marcum, and S.J. Anderson. 2002b. Registration of 'Cavalier'. Zoysiagrass. Crop Sci. 42:302-303.

Ervin, E.H., C.H. Ok, B.S. Fresenburg, and J.H. Dunn. 2002. Trinexapac-ethyl restricts shoot growth and prolongs stand density of 'Meyer' zoysiagrass fairway under shade. HortScience 37:502-505.

Gardner, D.S. and J.A. Taylor. 2002. Change over time in quality and cover of various turfgrass species and cultivars maintained in shade. HortTechnology 12:465-469.

Giesler, L.J., G.Y. Yuen, and G.L. Horst. 2000. Canopy microenvironments and applied bacteria population dynamics in shaded tall fescue. Crop Sci. 40:1325-1332.

Hart, S.W. and J.A. DeFrance. 1955. Behavior of Zoysia japonica 'Meyer' in cool-season turf. U.S. Golf Assoc. J. Turf Manage. 8:25-28.

Jiang, Y., R.N. Carrow, and R.R. Duncan. 2003. Effects of morning and afternoon shade in combination with traffic stress on seashore paspalum. HortScience 38:1218-1222.

Morris, K.N. 1996. National zoysiagrass test-1991. Final Report NTEP No. 96-15 Nat. Turfgrass Eval. Prog. NTEP No. 96-15.
Morris, K.N. and R.C. Shearman. 1998. NTEP turfgrass evaluation guidelines. NTEP Turfgrass Evaluation Workshop, Beltsville, MD. p. 1-5.

Qian, Y.L. and M.C. Engelke. 1999. 'Diamond' zoysiagrass as affected by light intensity. J. of Turfgrass Mgt. 3:1-13.

Qian, Y.L., M.C. Engelke, M.J.V. Foster, and S. Reynolds. 1998. Trinexapac-ethyl restricts shoot growth and improves quality of ' $\mathrm{Di}$ amond' zoysiagrass under shade. HortScience 33:1019-1022.

Riffel, S.K., M.C. Engelke, and S.J. Morton. 1995. Performance of three warm-season turfgrasses cultured in shade: Zoysiagrass. Texas Turfgrass Res. Rep. 95-1:60-65.

Shnyder, H. and C.J. Nelson. 1989. Growth rate and assimilate partitioning in the elongation zone of tall fescue leaf blades at high and low irradiance. Plant Physiol. 90:1201-1206.

Sladek, B.S., G.M. Henry, and D.L. Auld. 2009. Evaluation of zoysiagrass genotypes for shade tolerance. HortScience 44:1447-1451.

Steinke, K. and J.C. Stier. 2004. Influence of trinexapac-ethyl on cold tolerance and nonstructural carbohydrates of shaded supina bluegrass. Acta Hort. 661:207-215.

Stier, J.C. and D.S. Gardner. 2008. Shade stress and management, p. 463. In: Pessarakli, M. (ed.). Turfgrass management and physiology. CRC Press, Boca Raton, FL.

Tan, Z.G. and Y.L. Qian. 2003. Light intensity affects gibberellic acid content in kentucky bluegrass. HortScience 38:113-116.

Turgeon, A.J. 2002. Turfgrass management. Prentice Hall, Upper Saddle River, NJ.

Vargas, J.M. and J.B. Beard. 1981. Shade environment-disease relationships of kentucky bluegrass cultivars, p. 391-395. In: Sheard, R.W. (ed.). Proc. 4th Intl. Turfgrass Res. Conf. Intl. Turfgrass Soc. Ontario Agr. College, University of Guelph, Guelph, Ontario, Canada.

Watkins, E., S. Fei, D. Gardner, J. Stier, S. Bughrara, D. Li, C. Bigelow, L. Schleicher, B. Horgan, and K. Diesburg. 2011. Low-input turfgrass species for the north-central United States. J. Appl. Turf. Sci. doi:10.1094/ATS2011-0126-02-RS.

Wherley, B.G., D.S. Gardner, and J.D. Metzger. 2005. Tall fescue photomorphogenesis as influenced by changes in spectral composition and light intensity. Crop Sci. 45:562-568.

Whitcomb, C.E. 1972. Influence of tree root competition on growth of four cool-season turfgrasses. Agron. J. 64:355-359.

Whitcomb, C.E. and E.C. Roberts. 1973. Competition between established tree roots and newly seeded kentucky bluegrass. Agron. J. 65:126129.

Winstead, C.W. and C.Y. Ward. 1974. Persistence of southern turfgrasses in a shade environment. In: Roberts, E.C. (ed.). Proc. 2nd Intl. Turfgrass Res. Conf. 2:221-230.

Zarlengo, P.J., C.S. Rothrock, and J.W. King. 1994. Influence of shading on the response of tall fescue cultivars to Rhizoctonia solani AG-1 IA Plant Dis. 78:126-129. 